\title{
Influence of insemination-ovulation interval and sperm cell dose on fertilization in sows
}

\author{
D. W. B. Steverink, N. M. Soede, E. G. Bouwman and B. Kemp \\ Wageningen Institute of Animal Sciences (WIAS), Wageningen Agricultural University, PO Box 338, \\ 6700 AH, Wageningen. The Netherlands
}

\begin{abstract}
This experiment was conducted to determine the effects of sperm dose at insemination on fertilization rates and accessory sperm cells attached to day 5 embryos. Multiparous sows $(n=115)$ were artificially inseminated once with $1 \times 10^{9}, 3 \times 10^{9}$ or $6 \times 10^{9}$ sperm cells between $3 \mathrm{~h}$ and $48 \mathrm{~h}$ before ovulation. Transrectal ultrasonography was performed at intervals of $4 \mathrm{~h}$ to determine the time of ovulation and sows were killed at $120 \pm 5 \mathrm{~h}$ after ovulation to assess the results of fertilization. The insemination-ovulation interval had a major influence on the fertilization rate and accessory sperm count. A nonsignificant but consistent increase in fertilization rate and in number of accessory sperm cells due to the sperm dose was observed. During the insemination-ovulation interval of $12-24 \mathrm{~h}$, the median fertilization rates were $95 \%, 100 \%$ and $100 \%$, and the median accessory sperm counts were 11,17 and 31 for the $1 \times 10^{9}, 3 \times 10^{9}$ and $6 \times 10^{9}$ doses, respectively. During the insemination-ovulation interval of $24-36 \mathrm{~h}$, the median fertilization rates were $88 \%$, $95 \%$ and $97 \%$, and the median accessory sperm counts were 6,8 and 11 for the $1 \times 10^{9}$, $3 \times 10^{9}$ and $6 \times 10^{9}$ doses, respectively. No direct relationship was detected between embryo quality and the accessory sperm count but there was a relationship between insemination-ovulation interval and accessory sperm count. The fertilization rate was positively correlated with the breeding value for litter size of the sows. In conclusion, the effects of sperm dose on fertilization rate and on accessory sperm count in sows were small and nonsignificant, indicating only small effects of sperm dose on the functioning of the sperm reservoir in the sow.
\end{abstract}

\section{Introduction}

At insemination or mating in pigs, billions of sperm cells are deposited in the uterus. From this site, spermatozoa start to migrate towards the site of sperm storage which is in the first $2 \mathrm{~cm}$ of the caudal region of the isthmus in the oviduct (Hunter, 1981). When sperm cells reach the reservoir, they can be stored without a reduction of the motility, viability and fertilization capacity (Overstreet et al., 1980; Suarez et al., 1991), which makes the reservoir a temporal shelter to bridge the time until fertilization of oocytes. Sperm cells can be stored in the reservoir for up to $40 \mathrm{~h}$ (Hunter, 1981; Pollard et al., 1991; Raycoudhurry and Suarez, 1991).

Relative to the number of sperm cells inseminated, only a small number reach the isthmic sperm reservoir (Hunter, 1981). Before the sperm cells reach the oviduct they have to pass a major barrier: the uterotubal junction (Smith et al., 1987). Fewer dead (Viring, 1980), heterologous (pigs: Baker et al., 1968; hamsters: Smith et al., 1988) or capacitated spermatozoa (Shalgi et al., 1992) pass the uterotubal junction compared with normal spermatozoa. Spermatozoa that do not reach the sperm reservoir in time are killed by the hostile uterine environment. In the

Revised manuscript received 25 March 1997 hamster uterus, the motility of spermatozoa decreases from $60 \%$ immediately before insemination to $10 \%$ at $1 \mathrm{~h}$ after insemination (Smith $e$ al., 1988). The spermatozoa that do not reach the sperm reservoir are removed by backlow (Viring and Einarsson, 1981) or local phagocytosis, which is seen within $2 \mathrm{~h}$ of insemination (Pursel et al., 1978).

Fertilization rate is dependent on the time interval between insemination and ovulation. In sows, fertilization rate is optimal when insemination with $3 \times 10^{9}$ sperm cells occurs between $0 \mathrm{~h}$ and $24 \mathrm{~h}$ before ovulation (Soede et al, 1995a). Nissen et al. (1997) found an optimal insemination time with $2 \times 10^{9}$ sperm cells, between $28 \mathrm{~h}$ before ovulation and $4 \mathrm{~h}$ after ovulation, based on a high farrowing rate and a large litter size in multiparous sows. Furthermore, Soede et al. (1995a) showed that the number of accessory sperm cells attached to the zona pellucida of the embryos fell rapidly when the interval between insemination and ovulation increased. Accessory spermatozoa represent a population of spermatozoa able to traverse the barriers of the female reproductive tract and partially penetrate the zona pellucida at fertilization (Weitze et al., 1988; Saacke et al., 1994). With an increase in the interval between insemination and ovulation, the number of potentially fertilizing sperm cells and, consequently, the accessory sperm cells and the fertilization rate decreased. The question arises whether it is 
possible to increase the number of sperm cells at the site of fertilization by increasing the number of sperm cells in the reservoir by using a greater number of sperm cells at insemination. This might extend the insemination-ovulation interval within which good fertilization results can be achieved compared with the $0-24 \mathrm{~h}$ found with $3 \times 10^{9}$ sperm cells. A second question is whether the number of sperm cells at the site of fertilization might be decreased by decreasing the number of sperm cells at insemination and, thereby, shortening the insemination-ovulation interval in which good fertilization results can be achieved compared with the $0-24 \mathrm{~h}$ found with $3 \times 10^{9}$ sperm cells. In an in vitro study (Lefebvre and Suarez, 1996), the number of spermatozoa bound to oviductal epithelium was found to be dependent on the concentration of sperm cells. Bovine isthmus epithelium was incubated for 15-30 min with $1 \times 10^{5}$ motile sperm cells, after which 30 sperm cells bound to $0.1 \mathrm{~mm}^{2}$ epithelium, whereas incubation with $1 \times 10^{6}$ sperm cells resulted in 600 sperm cells bound to $0.1 \mathrm{~mm}^{2}$ epithelium. This change in number of sperm cells bound to oviduct epithelium in vitro might also occur in vivo and, as a consequence, increase fertilization rate.

The two hypotheses of this study are (I) that fertilization rates are lower when a smaller number of sperm cells $\left(1 \times 10^{9}\right)$ are inseminated within $24 \mathrm{~h}$ before ovulation; and (2) that fertilization rates are higher when a greater number of sperm cells $\left(6 \times 10^{9}\right)$ are inseminated more than $24 \mathrm{~h}$ before ovulation. The objective of this study was to investigate the effects of the number of sperm cells at insemination on the fertilization rate and number of accessory sperm cells at 5 days after ovulation.

\section{Materials and Methods}

\section{Animals and housing}

For a period of 16 weeks, every 2 weeks, $9-22$ sows (139 in total) were obtained on the day of weaning. At the experimental farm, the sows were housed individually in crates and received a total of $2.5 \mathrm{~kg}$ of a commercial sow diet (I2.9 MJ $\mathrm{ME} \mathrm{kg}^{-1}$ ) in two portions daily and $2 \mathrm{~h}$ water ad libitum after feeding. Sows that came into oestrus and ovulated 3-7 days after weaning $(n=115)$ were assigned to the study. The sows arrived from one commercial farm, from two synthetic lines (A, $n=75$ and $B, n=40$ ) which were terminal sire lines of fattening pigs (Dalland b.v., Merselo). The original breeds of the lines were: Pietrain, Large White and Dutch Landrace. All sows had a breeding value for litter size (range: $1.06-1.13$ piglets) that was calculated based on their own and sib-relation performances. The sows were healthy upon clinical inspection. The number of sows from parity I to 7 was $36,14,36,25,3,0$ and 1 , respectively.

\section{Oestrus}

Detection of oestrus was performed at intervals of $8 \mathrm{~h}$, from $64 \mathrm{~h}$ after weaning until the end of oestrus. For every oestrus detection, the back pressure test was performed, first in the absence and then in the presence of a boar. The time of onset of oestrus was defined as the first time a sow showed a standing response minus $4 \mathrm{~h}$. The time of end of oestrus was defined as the last time a sow showed a standing response plus $4 \mathrm{~h}$.

\section{Ovulation}

Ovulation was detected using transrectal ultrasonography as described by Soede et al. (1992). An annular array sector scanner (type 150V, Pie Medical b.v., Maastricht,) with a 5.0-7.5 MHz multiple scan angle transducer was used. A first check of the ovaries for presence and size of follicles (diameter of antrum $>4 \mathrm{~mm}$ ) and corpora lutea was performed approximately $70 \mathrm{~h}$ after weaning. From $16 \mathrm{~h}$ after the onset of oestrus, ovaries were checked at intervals of $4 \mathrm{~h}$ to estimate the moment of ovulation. Time of ovulation was defined as the first time when no follicles were counted minus $2 \mathrm{~h}$. When the number of follicles was noticeably smaller than the previous scanning, ovulation was assumed to have just started, since ovulation takes on average $2 \mathrm{~h}$ in spontaneously ovulating sows (Soede et al., 1992). Ovulation was confirmed by one additional scanning $4 \mathrm{~h}$ later.

\section{Insemination}

Artificial insemination was conducted once with doses of $1 \times 10^{9}, 3 \times 10^{9}$ or $6 \times 10^{9}$ mixed sperm cells from three boars in $80 \mathrm{ml}$. The age of the inseminated sperm cells (time from collection) was on average $23 \pm 7 \mathrm{~h}$ with a range of $11-36 \mathrm{~h}$ at the moment of insemination. Sperm quality was assessed for 3 consecutive days in samples of the sperm cell doses (magnification $\times 200$ ) by determining motile spermatozoa $(0 \%$ to $100 \%)$ and quality of motility $(0=$ very bad movement; $10=$ very good movement). At day 0 , the percentage of motile spermatozoa varied from $70 \%$ to $80 \%$, and the quality of motility varied from 7 to 8 . At day 2 , the percentage of motile spermatozoa varied from $60 \%$ to $80 \%$, and the quality of motility varied from 6 to 7 .

The moment of insemination depended on the predicted moment of ovulation. The predicted moment of ovulation was obtained from the interval between weaning and the onset of oestrus, based on data from Soede et al. (1995a, b). The $1 \times 10^{9}$ dose was inseminated at the predicted insemination-ovulation interval of $12-24 \mathrm{~h}$. The $6 \times 10^{9}$ dose was inseminated at the predicted insemination-ovulation interval of $24-36 \mathrm{~h}$. The reference $3 \times 10^{9}$ dose was inseminated at the predicted insemination-ovulation intervals of $12-24 \mathrm{~h}$ and $24-36 \mathrm{~h}$. The sows were assigned randomly to the treatment groups.

Before insemination, sows were taken to the boar pen for 5 min boar stimulation. Artificial insemination took place for each sow in her own cage. During insemination, the backlow of semen was collected with a $200 \mathrm{ml}$ cup which was then weighed on a balance.

\section{Embryonic development}

Sows were slaughtered $120 \pm 5 \mathrm{~h}(111-131 \mathrm{~h})$ after ovulation and the embryos were collected immediately. Both oviducts were flushed with $15 \mathrm{ml}$ Dulbecco's PBS (DPBS) from the infundibulum to the uterus. The oviducts were then Downloaded from Bioscientifica.com at 04/26/2023 12:13:13PM 
separated from the uterus and each uterine horn was flushed twice with $30 \mathrm{ml}$ DPBS to collect the embryos and oocytes. The quality and morphology of the recovered embryos and oocytes were assessed (magnification $\times 60$ ) at the laboratory. Thereafter, embryos and oocytes were subjected to hypotonic treatment $\left(0.6 \%(\mathrm{w} / \mathrm{v}) \mathrm{KCl}, 0^{\circ} \mathrm{C}, 10 \mathrm{~min}\right)$ and subsequently placed on a fat-free glass slide. Small droplets of methanol/ acetic acid $(3 / 1 \mathrm{v} / \mathrm{v})$ were added until disruption and spreading of the embryo (generally $1 \mathrm{~cm}^{2}$ ) to allow the nuclei and spermatozoa to be counted (magnification $\times 200$ ) after drying and staining with $10 \%(\mathrm{v} / \mathrm{v})$ Giemsa (Merck, Darmstadt) in PBS. An oocyte was classified as unfertilized if the nuclei count was 0 or 1 . Embryos with degenerated morphology and a small number of nuclei were classified as degenerated embryos. The remaining embryos were considered normal. Recovery rate per sow was determined as the percentage of embryos and oocytes recovered, based on the number of corpora lutea. The rate of normal and degenerated embryos and oocytes was determined on the basis of the total number of recovered embryos and oocytes per sow. Fertilization rate was determined as the percentage of normal and degenerated embryos among the total recovered embryos and oocytes per sow.

\section{Statistical analyses}

Data were analysed using SAS (1990). Data are presented as mean $\pm S D$ and a range (minimum-maximum) or least squares means \pm SEM when correction for specific factors was relevant.

The two synthetic lines used did not differ in any respect. The duration of oestrus (h) was analysed using the general linear models (GLM) procedure with the following factors: parity (two classes) and weaning to oestrus interval (h). Parity was divided into two classes: 'young' sows (parity $I$ and 2) and 'older' sows (parity 3-7). The time of ovulation (h) during oestrus was analysed using the GLM procedure with the factor duration of oestrus (h).

The influence of embryonic age $(h)$ on embryonic development (cell cycles) was analysed using the GLM procedure. Embryonic development was expressed as the average number of cell cycles $\left({ }^{2} \log (\right.$ nuclei count)) per sow. The embryonic age (h) was defined as the period between ovulation and slaughter of the sow.

Proportions of unfertilized, degenerated and normal embryos per sow underwent a normalizing arcsine transformation before analysis (Snedecor and Cochran, 1989). These proportions of embryos were analysed using the Wilcoxon test of the NPARIWAY procedure with the factors: inseminationovulation interval (four classes: $0-12 \mathrm{~h}, 12-24 \mathrm{~h}, 24-36 \mathrm{~h}$ and $36-48 \mathrm{~h}$ ) and insemination doses (three classes: $1 \times 10^{9}, 3 \times 10^{9}$ and $6 \times 10^{9}$ sperm cells).

The number of accessory sperm cells attached to normal embryos showed a lognormal distribution; therefore, the ${ }^{10} \mathrm{log}$ (accessory sperm count per embryo) transformation was applied before the analysis. The accessory sperm cells were analysed using the Wilcoxon test of the NPARIWAY procedure with the factors: insemination-ovulation interval (four classes: $0-12 \mathrm{~h}, 12-24 \mathrm{~h}, 24-36 \mathrm{~h}$ and $36-48 \mathrm{~h}$ ) and insemination doses (three classes: $1 \times 10^{9}, 3 \times 10^{9}$ and $6 \times 10^{9}$ sperm cells). The influence of the continuous insemination-ovulation interval (h) on accessory sperm cells was analysed using the GLM procedure.

Sows were divided into four classes, depending on their fertilization rate: $100-90 \%, 90-80 \%, 80-50 \%$ and $50-0 \%$. The distribution of the proportions of fertilization rates of the sows in the classes of insemination-ovulation interval (four classes: $0-12 \mathrm{~h}, 12-24 \mathrm{~h}, 24-36 \mathrm{~h}$ and $36-48 \mathrm{~h}$ ) and insemination doses (three classes: $1 \times 10^{9}, 3 \times 10^{9}$ and $6 \times 10^{9}$ sperm cells) was analysed with chi-square of the frequency (FREQ) procedure.

The effect of sperm dose $\left(1 \times 10^{9}, 3 \times 10^{9}\right.$ and $6 \times 10^{9}$ sperm cells) on fertilization rate was analysed in a continuous scale of insemination-ovulation intervals between $0 \mathrm{~h}$ and $48 \mathrm{~h}$. The analysis of variance on arcsine transformed fertilization rates was done with the GLM procedure with the factors: insemination-ovulation time $(0-48 \mathrm{~h})$; sperm cells in dose (three classes: $1 \times 10^{9}, 3 \times 10^{9}$ and $6 \times 10^{9}$ sperm cells); parity (two classes: 'young' and 'old' sows) and breeding value for litter size ( -1.06 to 1.13 piglets).

\section{Results}

\section{Animals}

Of the 139 sows obtained, 19 sows did not show oestrus before 7 days after weaning, three sows had more than $20 \mathrm{ml}$ backflow of semen during insemination, one sow had an insemination-ovulation interval of more than $50 \mathrm{~h}$, and one sow had one uterine horn. These sows were excluded from the study.

\section{Oestrus and ovulation}

In the 115 sows remaining, the weaning-oestrus interval was $92 \pm 15 \mathrm{~h}$, with a range of $65-132 \mathrm{~h}$ that was not affected by parity $(P>0.05)$. The average duration of oestrus of all the sows was $59 \pm 12 \mathrm{~h}$, with a range of $24-88 \mathrm{~h}$. The duration of oestrus was significantly shorter $(P=0.002)$ in the young sows (parity 1 and 2: $55 \pm 11 \mathrm{~h}, n=50$ ) compared with the older sows (parity 3-7: 62 $\pm 12 h, n=65$ ). The duration of oestrus was not significantly related to the weaning-oestrus interval $(P=0.18)$.

Time of ovulation in hours after the onset of oestrus (OV) during oestrus was related to the duration of oestrus in hours (OEST): $\mathrm{OV}=8.6+0.5 \times$ OEST $\left(R^{2}=59 \%, P<0.0001\right.$, $n=114)$. On average, ovulation took place at $68 \pm 10 \%$ of the oestrous period.

\section{Embryos and oocytes}

Sows had a mean number of $21.1 \pm 6.1$ corpora lutea. The number of recovered embryos and oocytes compared with the number of corpora lutea varied from $55 \%$ to $100 \%$, with a mean of $89 \pm 6.8 \%$.

Fertilization rate varied between $0 \%$ and $100 \%$ per sow. Degenerated embryos appeared in $36 \%$ of the sows; the mean percentage of degenerated embryos in all sows was $4 \pm 8 \%$. The number of degenerated embryos was not affected by insemination dose $(P=0.29)$ nor by the inseminationovulation interval $(P=0.19)$. The proportion of unfertilized 


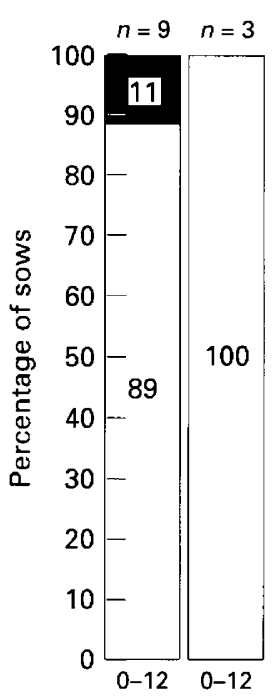

13

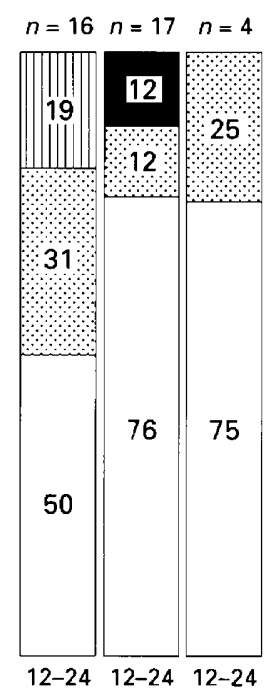

Insemination-ovi

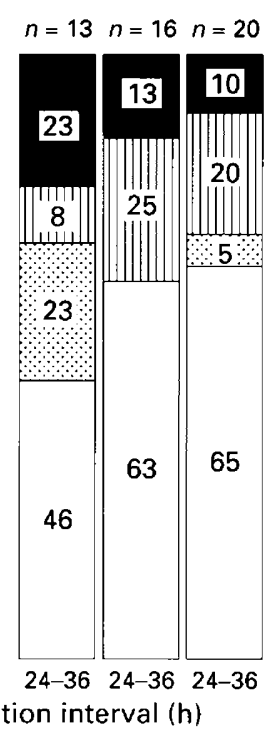

$\begin{array}{lll}1 & 3 & 6\end{array}$

\section{Sperm dose $\times 10^{-9}$}

Fig. 1. The percentage of sows displaying bad $(0-50 \%$, $)$, poor $(50-80 \%$, 四), moderate $(80-90 \%$, ק) and good $(90-100 \%, \square)$ fertilization rates after artificial insemination with $1 \times 10^{9}, 3 \times 10^{9}$ or $6 \times 10^{9}$ sperm cells with insemination-ovulation interval classes of $10-12 \mathrm{~h}, 12-24 \mathrm{~h}, 24-36 \mathrm{~h}$ and $36-48 \mathrm{~h}$.

embryos was similar to the reciprocal of the proportion of normal embryos per sow, because of the small number and equal distribution of degenerated embryos.

The mean age of the embryos was $120 \pm 4.5 \mathrm{~h}$ and varied between 111 and $131 \mathrm{~h}$. The average development of the normal embryos per sow varied between 3.7 and 7.3 cell cycles. The development of normal embryos was not significantly affected by the insemination dose $(P=0.89)$ or insemination-ovulation interval classes $(P=0.45)$. The variation in embryo development between sows was related to the age of the embryos in hours (AGE); cell cycles $=-1.17+$ $0.055 \times \operatorname{AGE}\left(R^{2}=14 \%, P<0.0001, n=107\right)$; at an embryo age of $120 \mathrm{~h}$, the mean development was 5.4 cell cycles.

\section{Fertilization results in $12 \mathrm{~h}$ insemination-ovulation interval classes}

The percentage of normal embryos varied considerably in all the insemination-ovulation interval classes from 0 to $100 \%$. The four classes of fertilization were defined as good fertilization (100-90\% normal embryos), moderate fertilization (90$80 \%$ normal embryos), poor fertilization $(80-50 \%$ normal embryos) and bad fertilization (50-0\% normal embryos). A shift of good fertilization to poor and bad fertilization was observed when the insemination-ovulation interval increased (Fig. I).

The median percentage of normal embryos was not significantly different between insemination doses $1 \times 10^{9}$ and $3 \times 10^{9}$ sperm cells in the insemination-ovulation interval of 12-24 h (Table 1). However, the percentages of sows in the four fertilization classes in the insemination-ovulation interval of $12-24 \mathrm{~h}$ were distributed significantly differently $(P<0.05)$ between the dose $1 \times 10^{9}$ and $3 \times 10^{9}$ sperm cells (Fig. 1). The dose of $1 \times 10^{9}$ sperm cells resulted in $26 \%$ fewer sows with good fertilization results (100-90\% normal embryos) and $19 \%$ more sows with moderate fertilization results $(80-90 \%$ normal embryos) compared with the dose $3 \times 10^{9}$ sperm cells (Fig. 1).

The median percentage of normal embryos was not significantly different between insemination doses $3 \times 10^{9}$ and $6 \times 10^{9}$ sperm cells in the insemination-ovulation interval of $24-36 \mathrm{~h}$ (Table 1). The percentages of sows in the four fertilization classes in the insemination-ovulation interval of 24-36 h were not distributed significantly differently $(P<0.05)$ between the dose $3 \times 10^{9}$ and $6 \times 10^{9}$ sperm cells (Fig. 1). However, the fertilization results of sows inseminated with $1 \times 10^{9}$ sperm cells in this insemination-ovulation interval were distributed significantly differently compared with the higher sperm doses $(P<0.05)$. The sows inseminated with $1 \times 10^{9}$ sperm cells had a higher percentage of sows $(23 \%)$ with moderate fertilization results (Fig. 1).

Insemination between $36 \mathrm{~h}$ and $48 \mathrm{~h}$ before ovulation with $3 \times 10^{9}$ and $6 \times 10^{9}$ sperm cells did not result in a significantly different distribution of sows among the four fertilization classes (Fig. 1). However, the dose $6 \times 10^{9}$ sperm cells still resulted in $28 \%$ sows with good fertilization results, whereas the dose $3 \times 10^{9}$ resulted in $\%$ sows with good fertilization.

\section{Percentage of normal embryos in a continuous insemination-ovulation interval $(0-48 \mathrm{~h})$}

An analysis of variance on the transformed percentage of normal embryos per sow showed significant correlations $\left(R^{2}=0.28 ; P<0.0001\right)$ with the following variables. The effect 
Table 1. Fertilization results in sows that were inseminated at $12-24 \mathrm{~h}$ and $24-36 \mathrm{~h}$ before ovulation with an insemination dosage of $1 \times 10^{9}, 3 \times 10^{9}$ and $6 \times 10^{9}$ sperm cells

\begin{tabular}{|c|c|c|c|c|}
\hline \multirow[b]{2}{*}{ Dosage (number of sperm cells) } & \multicolumn{2}{|c|}{$\begin{array}{l}\text { Insemination } \\
\text { 12-24 h before } \\
\text { ovulation }\end{array}$} & \multicolumn{2}{|c|}{$\begin{array}{l}\text { Insemination } \\
24-36 \text { h before } \\
\text { ovulation }\end{array}$} \\
\hline & $1 \times 10^{9}$ & $3 \times 10^{9}$ & $3 \times 10^{9}$ & $6 \times 10^{9}$ \\
\hline Sows $(n)$ & 16 & 17 & 16 & 20 \\
\hline Insemination-ovulation interval (h) & $19 \pm 3$ & $20 \pm 3$ & $29 \pm 4$ & $30 \pm 3$ \\
\hline \multicolumn{5}{|l|}{ Normal embryos $(\%)$} \\
\hline Mean & $89 \pm 15$ & $88 \pm 28$ & $83 \pm 22$ & $83 \pm 26$ \\
\hline Median & 95 & 100 & 95 & 97 \\
\hline Range & $55-100$ & $0-100$ & $42-100$ & $6-100$ \\
\hline \multicolumn{5}{|l|}{ Accessory sperm count } \\
\hline Mean & $30 \pm 41$ & $22 \pm 20$ & $16 \pm 18$ & $11 \pm 9$ \\
\hline Median & 11 & 17 & 8 & 11 \\
\hline Range & $I-147$ & $2-66$ & $0-57$ & $0-28$ \\
\hline
\end{tabular}

Within an insemination-ovulation interval, there were no significant differences between sperm doses $(P>0.05)$.

of insemination-ovulation interval is negative and highly significant $(b=-0.019 \pm 0.003 ; P<0.0001)$, which means that an increase of the insemination-ovulation interval by $24 \mathrm{~h}$ resulted in a decrease of $20 \%$ in the percentage of normal embryos. Sperm dose tends to affect the percentage of normal embryos $(P=0.096)$; the doses $1 \times 10^{9}, 3 \times 10^{9}$ and $6 \times 10^{9}$ sperm cells resulted in $78 \pm 0.3 \%, 84 \pm 0.3 \%$ and $91 \pm 0.4 \%$ normal embryos (LSM \pm SEM), respectively. The 'young' sows (parity 1 and 2 ) had significantly lower $(P=0.026)$ percentages of normal embryos $(79.1 \%$ ) than the 'old' sows (parity 3-7) $(88.8 \%)$. The genetic background of the sows, based on the breeding value for litter size, also influenced the percentage of normal embryos in the sows $(b=0.21 \pm 0.05 ; P=0.0026)$. An increase in breeding value of one piglet increased the percentage of normal embryos by $4.5 \%$.

\section{Accessory sperm count}

The accessory sperm count on normal embryos is highly variable among and within sows and within the doses $1 \times 10^{9}$, $3 \times 10^{9}$ and $6 \times 10^{9}$ sperm cells (Fig. 2). In the inseminationovulation interval of $0-12 \mathrm{~h}$, the doses $1 \times 10^{9}, 3 \times 10^{9}$ and $6 \times 10^{9}$ sperm cells had median accessory sperm counts of 22 , 178 and -, respectively; in the interval of $12-24 \mathrm{~h}$, the median accessory sperm counts were 11,17 and 31 , respectively; in the insemination-ovulation interval of 24-36 h, the median accessory sperm counts were 6,8 and 11 , respectively; and in the insemination-ovulation interval of $36-48 \mathrm{~h}$, the mean accessory sperm counts were 0,4 and 8 , respectively. The accessory sperm count was not significantly different among the insemination doses in any of the insemination-ovulation interval classes. Sows inseminated with $1 \times 10^{9}$ sperm cells had a significantly higher $(P<0.05)$ median accessory sperm count in the insemination-ovulation intervals of $0-12 \mathrm{~h}$ and $12-24 \mathrm{~h}$ (22 and 11, respectively) compared with the inseminationovulation interval $24-36 \mathrm{~h}(6)$. Sows inseminated with $3 \times 10^{9}$ sperm celis had a significantly higher $(P<0.05)$ median accessory sperm count in the insemination-ovulation interval of
$0-12 \mathrm{~h}$ (178) compared with the insemination-ovulation intervals of $12-24 \mathrm{~h}, 24-36 \mathrm{~h}$ and $36-48 \mathrm{~h}(17,6$ and 4 , respectively). Sows inseminated with $6 \times 10^{9}$ sperm cells had a significantly higher $(P<0.05)$ median accessory sperm count in the insemination-ovulation intervals of $12-24 \mathrm{~h}$ and $24-36 \mathrm{~h}$ (31 and 11) compared with the insemination-ovulation interval of 36-48 h (8). The median number of accessory sperm cells in sows with $100 \%$ normal embryos $(n=50)$ was 18 , with a range of 1.6-220 accessory sperm cells.

The accessory sperm count decreased significantly with an increase in the insemination-ovulation interval. The effect of insemination-ovulation interval in hours (IO) on accessory sperm count (ASPERM) was: ${ }^{10} \log ($ ASPERM $)=1.63-$ $0.028 \times \mathrm{IO} ;\left(R^{2}=0.24, p<0.0001, n=101\right)$.

\section{Discussion}

Fertilization rates at day 5 of gestation were not significantly affected by insemination dose $1 \times 10^{9}$ versus $3 \times 10^{9}$ in the insemination-ovulation interval of $12-24 \mathrm{~h}$ and not affected by insemination dose $3 \times 10^{9}$ versus $6 \times 10^{9}$ in the inseminationovulation interval of $24-36 \mathrm{~h}$. However, both the median percentage of normal embryos and the median accessory sperm count increased with an increase in insemination dose in all the insemination-ovulation classes $0-12 \mathrm{~h}, 12-24 \mathrm{~h}, 24-36 \mathrm{~h}$ and $36-48 \mathrm{~h}$.

A positive effect of increased number of sperm cells at insemination on fertilization was expected. For example, Baker et al. (1968) compared insemination doses $1 \times 10^{9}$ and $5 \times 10^{9}$ sperm cells in ten gilts inseminated $6-8 \mathrm{~h}$ before ovulation and found $24 \%$ versus $73 \%$ fertilized eggs $6-8 \mathrm{~h}$ after ovulation respectively. The results in vivo of the expected increased number of sperm cells are supported by experiments in vitro. Lefebvre and Suarez (1996) showed that the number of sperm cells bound per $\mathrm{mm}^{2}$ isthmic epithelium in vitro was increased by using more sperm cells in the medium. Increased number of spermatozoa at insemination in vivo may result in an increased 


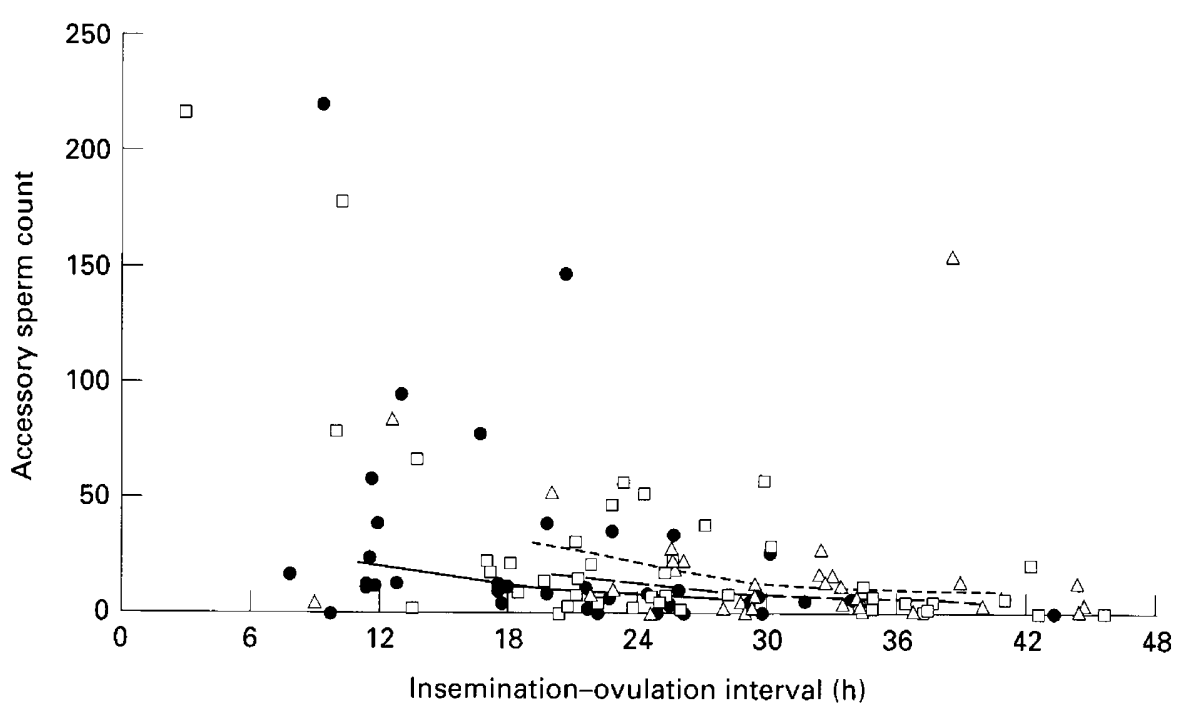

Fig. 2. The accessory sperm count on normal embryos per sow for the doses $1 \times 10^{9}(-\mathbf{-}-$ ), $3 \times 10^{9}(-\square-)$ or $6 \times 10^{9}(--\triangle--)$ sperm cells. The lines join the median accessory sperm count in the insemination-ovulation interval classes: $0-12 \mathrm{~h}, 12-24 \mathrm{~h}, 24-36 \mathrm{~h}$ and $36-48 \mathrm{~h}$ for the three doses.

length and, thereby, area of sperm reservoir, and also a higher density of sperm cells per $\mathrm{mm}^{2}$. Therefore, it seems logical that the functional filling of the sperm reservoir in pigs can be increased by increasing the number of inseminated sperm cells. In the present study, no evidence was found for an increased fertilization rate or accessory sperm count due to an increased number of sperm cells at insemination.

If a greater number of spermatozoa are deposited in the reservoir with a higher insemination sperm dose, the lack of dose effects might be explained by the release pattern from the reservoir. After filling the reservoir, the release of sperm cells from the reservoir is exponential in the first hours after insemination. Therefore, the differences between sperm doses may be visible only when the insemination-ovulation interval is short $(<12 \mathrm{~h}$ ). Baker et al. (1968) inseminated gilts $6-8 \mathrm{~h}$ before ovulation with $\mathrm{I} \times 10^{9}$ to $5 \times 10^{9}$ sperm cells and found a significant increase in the median accessory sperm count from 3 to 130. In the present study, differences in accessory sperm count between doses became progressively smaller with increasing insemination-ovulation interval. The lack of effect of sperm dose on fertilization rate does not mean that sperm reservoirs are not filled with different numbers of sperm cells due to different sperm doses. The regulation of the number of sperm cells bound to isthmic epithelium is still not understood. More research on reservoir filling, capacity and release of the sperm reservoir is necessary to understand these mechanisms better.

It has been suggested that large numbers of accessory sperm cells positively affect embryo quality (Hunter and Wilmut, 1984; DeJarnette et al., 1992; Nadir et al., 1993; Saacke et al., 1994 (review)). In the present study, the variation in accessory sperm count between animals is very high. In sows inseminated 0-12 $\mathrm{h}$ before ovulation, the mean accessory sperm count ranged from 1 to 216 . Many sows with $100 \%$ normal developed embryos had a low accessory sperm count. This finding suggests that there is not a direct relationship between embryo quality and accessory sperm count. The accessory sperm count is strongly related to the insemination-ovulation interval. In the present study, large numbers of accessory sperm cells ( $>75$ ) attached to normal developed embryos were found only when the insemination-ovulation interval was short $(<18 \mathrm{~h})$. A large number of accessory sperm cells is an indication of a short insemination-ovulation interval. A similar relation between accessory sperm count and inseminationovulation interval was found in the studies of Soede et al. (1995a, b). Therefore, the cause of a higher embryo quality (good developed embryos) mentioned by Hunter and Wilmut (1984), DeJarnette et al. (1992), Nadir et al. (1993) and Saacke et al. (1994) could be the result of a short inseminationovulation interval and not of the number of accessory sperm cells. For a correct interpretation of the relationship between accessory sperm count and embryo quality it is necessary to know the insemination-ovulation interval.

In the present study, a part of the variation in fertilization rate had a genetic basis. The percentage of normal embryos was positively correlated $\left(R^{2}=26 \%, P<0.01\right)$ to the breeding value for litter size of the sows. This means that the fertilization rate at day 5 of gestation is related to the number of piglets the sow potentially can produce. An enlargement of the optimal insemination-ovulation interval is seen in sows with a high breeding value. At present, there are no studies available describing relations between genetic potential for litter size in sows and their fertilization rate on day 5 of gestation.

In conclusion, no significant effect of the doses of $1 \times 10^{9}$, $3 \times 10^{9}$ and $6 \times 10^{9}$ sperm cells was seen on fertilization rate, nor on the accessory sperm count. The insemination-ovulation interval has a significant effect on the fertilization rate and accessory sperm count. The process and regulation of the filling, capacity and release of sperm cells in the reservoir are still not understood and require further study. 
The authors gratefully acknowledge the financial support of the Dutch Association of Artificial Insemination Centres for pigs and the assistance of P. J. G. H. Kamphuis and W. Hazeleger.

\section{References}

Baker RD, Dziuk PJ and Norton HW (1968) Effect of volume of semen, number of sperm and drugs on transport of sperm in artificially inseminated gilts Journal of Animal Science 27 88-93

DeJarnette JM, Saacke RG, Bame J and Vogler CJ (1992) Accessory sperm: their importance to fertility and embryo quality, and attempts to alter their numbers in artificially inseminated cattle Journal of Animal Science 70 484-491

Hunter RHF (1981) Sperm transport and reservoir in the pig oviduct in relation to the time of ovulation Journal of Reproduction and Fertility 63 109-117

Hunter RHF and Wilmut I (1984) Sperm transport in the cow: peri-ovulatory redistribution of viable cells within the oviduct Reproduction, Nutrition, Development 24 597-608

Lefebvre R and Suarez SS (1996) Effect of capacitation on bull sperm binding to homologous oviductal epithelium Biology of Reproduction 54 575-582

Nadir S, Saacke RG, Bame J, Mullins J and Degelos S (1993) Effect of freezing semen and dosage of sperm on number of accessory sperm, fertility, and embryo quality in artificially inseminated cattle Journal of Animal Science $\mathbf{7 1}$ 199-204

Nissen AK, Soede NM, Hyttel P, Schmidt M and D'Hoore L (1997) The influence of time of insemination relative to time of ovulation on farrowing frequency and litter size in sows, as investigated by ultrasonography Theriogenoiogy $\mathbf{4 7}$ 1571-1582

Overstreet JW, Katz DF and Johnson IL (1980) Motility of rabbit spermatozoa in the secretions of the oviduct Biology of Reproduction 22 1083-1088

Pollard JW, Plante C, King WA, Hansen PJ, Betteridge KJ and Suarez SS (1991) Fertilizing capacity of bovine sperm may be maintained by binding to oviductal epithelial cells Biology of Reproduction 44 102-107

Pursel VG, Schulman LL and Johnson LA (1978) Distribution and morphology of fresh and frozen-thawed sperm in the reproductive tract of gilts after artificial insemination Biology of Reproduction 19 69-76

Raycoudhurry SS and Suarez SS (1991) Porcine sperm binding to oviductal explants in culture Theriogenology 36 1059-1070
Saacke RG, Nadir S, Dalton J, Bame J, DeJarnette JM, Degelos S and Nebel RL (1994) Accessory sperm evaluation and bull fertility - an update Proceedings of the 15th Technical Conference on Artificial Insemination and Reproduction pp 57-67

SAS/STAT (1990) User's Guide SAS Institute Inc., Cary, NC

Shalgi R, Smith TT and Koyanagi F (1992) A quantitative comparison of the passage of capacitated and uncapacitated hamster spermatozoa through the uterotubal junction Biology of Reproduction 46 419-424

Smith TT, Koyanagi F and Yanagimachi R (1987) Distribution and number of spermatozoa in the oviduct of the golden hamster after natural mating and artificial insemination Biology of Reproduction 37 225-234

Smith TT, Koyanagi F and Yanagimachi R (1988) Quantitative comparison of the passage of homologous and heterologous spermatozoa through the uterotubal junction of the golden hamster Gamete Research 19 227-234

Snedecor GW and Cochran WG (1989) Statistical Methods (8th Edn) Iowa State University Press, Ames

Soede NM, Noordhuizen JPTM and Kemp B (1992) The duration of ovulation in pigs, studied by transrectal ultrasonography, is not related to early embry. onic diversity Theriogennology 38 653-666

Soede NM, Wetzels CCH, Zondag W, de Koning MAI and Kemp B (1995a) Effects of time of insemination relative to ovulation, as determined by ultrasonography, on fertilization rate and accessory sperm count in sows Journal of Reproduction and Fertility $10499-106$

Soede NM, Wetzels CCH, Zondag W, Hazeleger W and Kemp B (1995b) Effects of a second insemination after ovulation on fertilization rate and accessory sperm count in sows Journal of Reproduction and Fertility 105 135-140

Suarez S, Redfern K, Raynor P Martin F and Phillips DM (1991) Attachment of boar sperm to mucosal explants of oviduct in vitro: possible role in formation of a sperm reservoir Biology of Reproduction 44 998-1004

Viring S (1980) Distribution of live and dead spermatozoa in the genital tract of gilts at different times after insemination Acta Veterinaria Scandinavica 21 587-597

Viring S and Einarsson S (1981) Sperm distribution within the genital tract of naturally inseminated gilts Nordisk Veterinaermedicin 33 145-149

Weitze KF, Rath R, Pena Alfaro CE, Androde Moura CJ and Scheid I (1988) Influence of different sperm number and seminal plasma in the inseminate upon number and seminal plasma in the inseminate upon number of accessory spermatozoa in pig embryos 10th International Pig Veterinarian Society Congress, Rio de Janeiro p 313 